\title{
Assessment of fluoride in groundwater and urine, and prevalence of fluorosis among school children in Haryana, India
}

\author{
A. K. Haritash ${ }^{1} \cdot$ Ankur Aggarwal $^{1} \cdot$ Jigyasa Soni $^{1} \cdot$ Khyati Sharma $^{1} \cdot$ Mohnish Sapra $^{1} \cdot$ Bhupinder Singh $^{2}$
}

Received: 21 September 2017 / Accepted: 11 March 2018 / Published online: 19 March 2018

(c) The Author(s) 2018

\begin{abstract}
Considering the health effects of fluoride, the present study was undertaken to assess the concentration of fluoride in groundwater, and urine of school children in Bass region of Haryana state. Fluoride in groundwater was observed to vary from 0.5 to $2.4 \mathrm{mg} / \mathrm{l}$ with an average concentration of $0.46 \mathrm{mg} / \mathrm{l}$. On the other hand, $\mathrm{F}^{-}$in urine ranged from below the detection limit to $1.8 \mathrm{mg} / \mathrm{l}$ among girls and $0.17-1.2 \mathrm{mg} / \mathrm{l}$ among the boys. Higher average concentration of fluoride in urine $(0.65 \mathrm{mg} / \mathrm{l}$ for boys and $0.34 \mathrm{mg} / \mathrm{l}$ for girls) may be ascribed to exposure to bioavailable fluoride through food, milk, tea, toothpaste, etc., in addition to intake through groundwater. Relatively more intake of water and food by the boys might be the reason for more cases of severe dental fluorosis (44\%) among boys compared to girls (29\% cases of moderate to severe dental fluorosis). The groundwater quality for drinking was compromised with respect to dissolved solids, hardness, magnesium ions, and dissolved iron. Hydro-geochemical investigation revealed that rock-water interaction, in terms of direct cation exchange, dominantly regulates groundwater chemistry, and groundwater is of $\mathrm{Ca}-\mathrm{Na}-\mathrm{HCO}_{3}$ type.
\end{abstract}

Keywords Fluoride $\cdot$ Urine $\cdot$ Fluorosis $\cdot$ Groundwater $\cdot$ School children

\section{Introduction}

Fluorine is 13th most common element in the earth's crust and is widely distributed as fluorspar $\left(\mathrm{CaF}_{2}\right)$, fluorapatite $\left(\mathrm{Ca}_{5}\left(\mathrm{PO}_{4}\right)_{3}\right)$, and cryolite $\left(\mathrm{Na}_{3} \mathrm{AlF}_{6}\right)$. These minerals are easily soluble in water and, therefore, higher fluoride levels are observed in groundwater which interacts with fluoride containing rocks during percolation. Consumption of fluoride $(0.5-1.0 \mathrm{mg} / \mathrm{l})$ through drinking water is beneficial in terms of dental health preventing dental caries. But, higher levels of fluoride $(>1.5 \mathrm{mg} / \mathrm{l})$ may result in dental or skeletal fluorosis depending on the intensity and duration of exposure. Apart from drinking water, exposure may also occur through bioavailable fluoride present in milk, food, meat (IPCS 2002), toothpaste/dentifrice, tea, tobacco (Yadav et al.

A. K. Haritash

akharitash@dce.ac.in

1 Department of Environmental Engineering, Delhi Technological University, Bawana Road, Shahbad Daulatpur, Delhi 110042, India

2 Department of Basic and Applied Science, Bhagat Phool Singh Mahila Vishwavidyalaya, Khanpur Kalan, Sonepat, Haryana 131305, India
2007), fluoridated salt (García-Pérez et al. 2013), etc. United States Environmental Protection Agency (USEPA) recommended range on fluoride in drinking water is $0.7-1.2 \mathrm{mg} / \mathrm{l}$, effectively setting the maximum level at the lower end $(0.7 \mathrm{mg} / \mathrm{l})$ to maximize dental caries protection benefits and to prevent excessive fluoride exposure in the population which receives fluoridated salt. Absorption of ingested fluoride is observed to be $100 \%$ on empty/fasting stomach; and around $60 \%$ when taken with a calcium-rich diet (WHO 2002). Hector et al. (2009) reported that retention of fluoride in young children may be higher $(\approx 70 \%)$ on account of higher ingestion through food and dentifrice. Young children swallow a part of dentifrice voluntarily or involuntarily during brushing which may result in enhanced exposure to systemic fluoride. Once ingested, fluoride reaches the blood stream within $30 \mathrm{~min}$ to $02 \mathrm{~h}$ depending upon ease in digestion of food and absorption of fluoride. Blood/plasma fluoride level is a contemporary biomarker of exposure to fluoride. Apart from blood, bone surface area, saliva, milk is also contemporary biomarkers; and whereas nails and hair are biomarkers of recent exposure, bone and teeth are the biomarkers for historical exposure (WHO 2014). But, till date urine is considered as the most useful biomarker for 
fluoride exposure since it is widely used, relatively simple, and non-invasive (Szymaczek and Lewicka 2005).

Prevalence of dental fluorosis in early age (15-20 years) is an expression of higher exposure to fluoride, and it is fairly important since it affects permanent teeth leading to mild, moderate, or severe level of dental fluorosis. Some studies (García-Pérez et al. 2013; Del Carmen et al. 2016) have reported prevalence of dental fluorosis in school children of younger age groups of 8-12 years and $12-15$ years as well. Therefore, monitoring of urinary fluoride concentration is a useful tool to assess the exposure particularly among the children at places with problem of endemic fluoride. Continued exposure to high level of fluoride may lead to osteo/ skeletal fluorosis after the age of 30 years, but it shall be preceded with dental fluorosis. Skeletal fluorosis is accompanied by neurological, excessive tiredness, sleepiness, headache, and loss of sensation, altered reflexes, impotence, and loss of sphincter control. Some studies have reported (Jolly et al. 1974) that skeletal fluorosis is also associated with nervous system damage. Studies in USA had no clear evidence that consumption of water with fluoride level up to $8 \mathrm{mg} / \mathrm{l}$ had any association with dental and skeletal fluorosis, but the reports from India and China clearly present an evidence of dental fluorosis, osteosclerosis, and bone fracture at concentration of $6 \mathrm{mg} / \mathrm{l}$ (IPCS 2002). Investigations by different authors in China have reported an association between higher level of fluoride in drinking water and lower IQ of children (Zhao et al. 1996; Xiang et al. 2003). Therefore, it becomes important to study the exposure of children, particularly school children, towards higher level of fluoride in drinking water in areas with endemic fluoride problem. Apart from fluoride, it is important to classify the water in respect of suitability for drinking for rest of the chemical constituents (Haritash et al. 2016); and to determine the major geochemical processes responsible for regulating groundwater chemistry (Haritash et al. 2017).

\section{Materials and methods}

Haryana is a major agricultural state of India with an area of $44,212 \mathrm{Km}^{2}$, and it has regional pockets of high concentration of fluoride in groundwater throughout its stretch (Haritash et al. 2008). Bass village of Hisar district in Haryana was selected as the study area since it has been identified as a water-challenged site by Department of Science and Technology owing to the problem of fluoride in groundwater. The village is classified as exclusive rural area with a total population of about 15,000 people. The sources of groundwater (hand-pump, tube-well, and submersible pump) were identified to collect representative groundwater samples to determine fluoride, since groundwater is the primary source for drinking and irrigation. A total of 25 groundwater
Table 1 Concentration of fluoride in ground water and urine, and prevalence of fluorosis among school children in Bass village

\begin{tabular}{clll}
\hline Parameter & $\begin{array}{l}\text { Groundwater } \\
(n=25)\end{array}$ & $\begin{array}{l}\text { Urinary } \\
\text { fluoride (girls) } \\
(n=25)\end{array}$ & $\begin{array}{l}\text { Urinary } \\
\text { fluoride (boys) } \\
(n=25)\end{array}$ \\
\hline Range & & BDL & 0.17 \\
Min. & 0.10 & 1.80 & 1.20 \\
Max. & 2.40 & $0.34 \pm 0.44$ & $0.65 \pm 0.29$ \\
Mean \pm SD & $0.46 \pm 0.47$ & 23 & 32 \\
Prevalence & Nil & 48 & 24 \\
of fluorosis & Mild & 21 & 36 \\
$(\%)$ & Moderate & 8 & 8 \\
& Severe & & \\
\hline
\end{tabular}

samples were collected from various locations within the village and from the fields around the village. The schoolchildren aged between 15 and 18 years were chosen as subjects $(n=50)$ with equal number of both the genders to assess the exposure through urinary fluoride levels. The younger age-groups were excluded since it is difficult for the young children to hold urine for about $4 \mathrm{~h}$ after first meal of the day. The urine samples were collected during 1:00-2:00 PM in the afternoon to let the excretory concentration of ingested
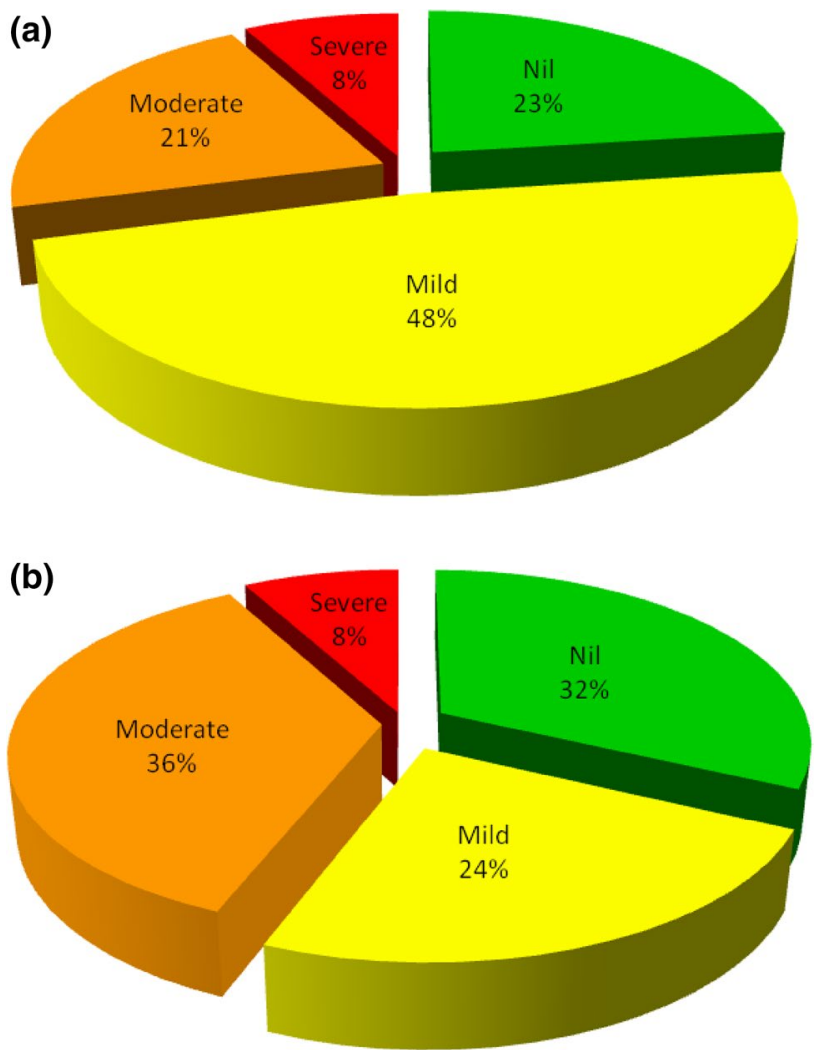

Fig. 1 Prevalence of fluorosis (\%) among girls (a) and boys (b) in the present study ( $n=25$ in each) 
Table 2 Suitability of groundwater for drinking in the present study

\begin{tabular}{|c|c|c|c|c|c|c|}
\hline \multirow[t]{2}{*}{ S. No. } & \multirow[t]{2}{*}{ Parameter } & \multicolumn{2}{|c|}{ Value/concentration } & \multicolumn{2}{|c|}{ Desirable limit } & \multirow{2}{*}{$\begin{array}{l}\text { Suitable } \\
\text { samples }(\%) \\
(n=25)\end{array}$} \\
\hline & & Range & Mean \pm SD & BIS (2012) & WHO (2006) & \\
\hline 1 & $\mathrm{pH}$ & $6.8-8.2$ & $7.5 \pm 0.33$ & $6.5-8.5$ & NM & $100^{\mathrm{a}}$ \\
\hline 2 & Total dissolved solids (TDS) (mg/l) & $58-5350$ & $1144 \pm 1192$ & 500 & NM & $24^{\mathrm{a}}$ \\
\hline 3 & $\begin{array}{l}\text { Total hardness (as } \mathrm{CaCO}_{3} \text { ) } \\
(\mathrm{mg} / \mathrm{l})\end{array}$ & $56-2740$ & $526 \pm 522$ & 200 & NM & $20^{\mathrm{a}}$ \\
\hline 4 & $\begin{array}{l}\text { Sodium }\left(\mathrm{Na}^{+}\right) \\
(\mathrm{mg} / \mathrm{l})\end{array}$ & $9-727$ & $186 \pm 208$ & NM & 200 & $64^{\mathrm{b}}$ \\
\hline 5 & $\begin{array}{l}\text { Calcium }\left(\mathrm{Ca}^{2+}\right) \\
(\mathrm{mg} / \mathrm{l})\end{array}$ & $8-331$ & $96 \pm 98$ & 75 & NM & $68^{\mathrm{a}}$ \\
\hline 6 & $\begin{array}{l}\text { Magnesium }\left(\mathrm{Mg}^{2+}\right) \\
(\mathrm{mg} / \mathrm{l})\end{array}$ & $0-463$ & $69 \pm 91$ & 30 & NM & $32^{\mathrm{a}}$ \\
\hline 7 & $\begin{array}{l}\text { Iron }(\mathrm{Fe}) \\
(\mathrm{mg} / \mathrm{l})\end{array}$ & $0.83-1.46$ & $0.91 \pm 0.12$ & 0.3 & 0.3 & $0^{\mathrm{a}}$ \\
\hline 8 & $\begin{array}{l}\text { Chloride }\left(\mathrm{Cl}^{-}\right) \\
(\mathrm{mg} / \mathrm{l})\end{array}$ & 14-701 & $171 \pm 226$ & 250 & 250 & $88^{\mathrm{a}}$ \\
\hline 9 & $\begin{array}{l}\text { Sulphate }\left(\mathrm{SO}_{4}{ }^{2-}\right) \\
(\mathrm{mg} / \mathrm{l})\end{array}$ & $21-315$ & $173 \pm 81$ & 200 & 500 & $56^{\mathrm{a}}$ \\
\hline 10 & $\begin{array}{l}\text { Nitrate }\left(\mathrm{NO}_{3}^{-}\right) \\
(\mathrm{mg} / \mathrm{l})\end{array}$ & $0.3-10.1$ & $4.9 \pm 3.1$ & 45 & 50 & $100^{\mathrm{a}}$ \\
\hline 11 & $\begin{array}{l}\text { Fluoride }\left(\mathrm{F}^{-}\right) \\
(\mathrm{mg} / \mathrm{l})\end{array}$ & $0.05-2.4$ & $0.46 \pm 0.47$ & 1.0 & 1.5 & $96^{\mathrm{a}}$ \\
\hline
\end{tabular}

$S D$ Standard deviation, $N M$ not mentioned

${ }^{\mathrm{a}}$ As per BIS

${ }^{\mathrm{b}}$ As per WHO

Fig. 2 Piper-trilinear diagram for geochemical classification of groundwater

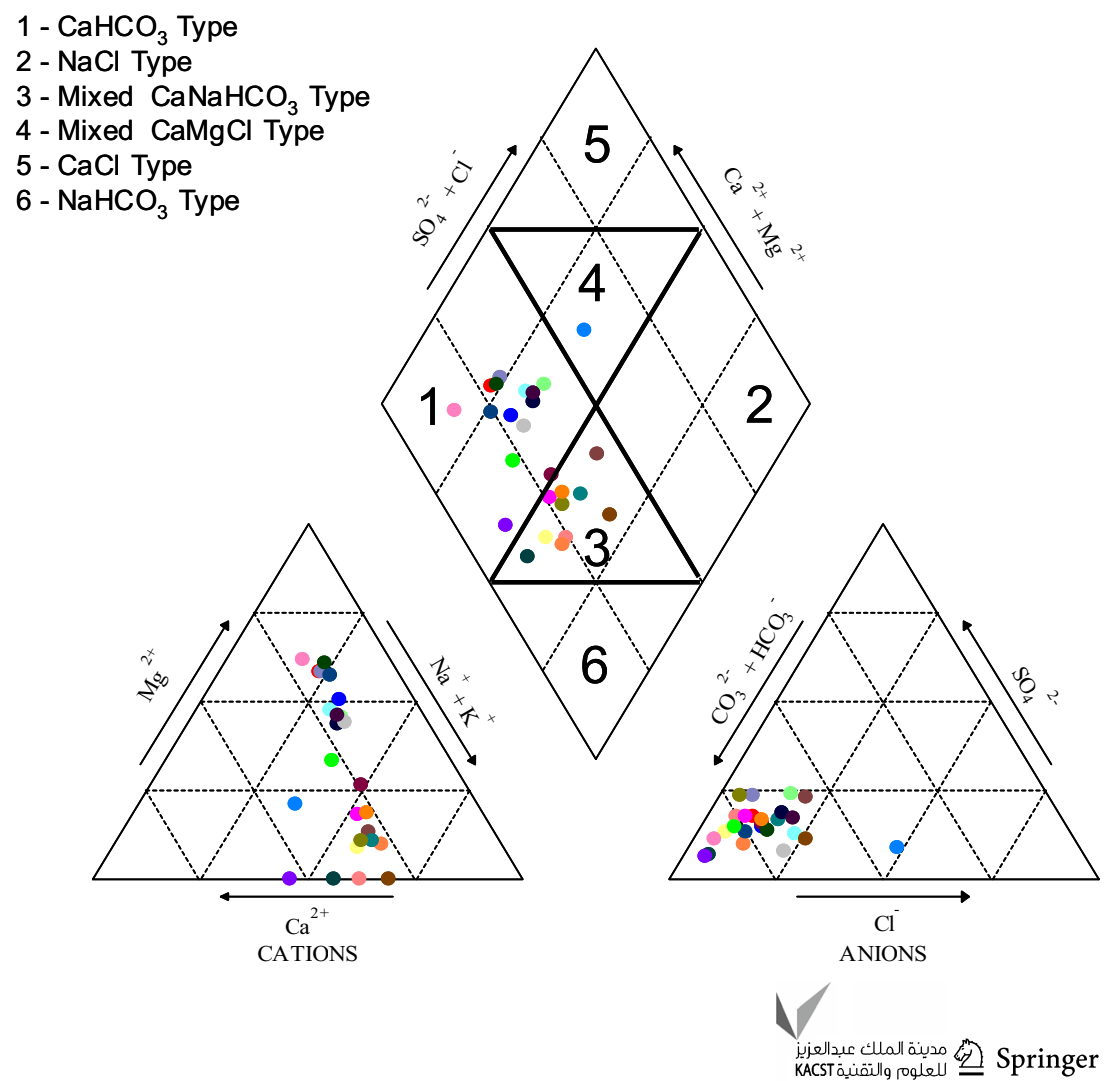




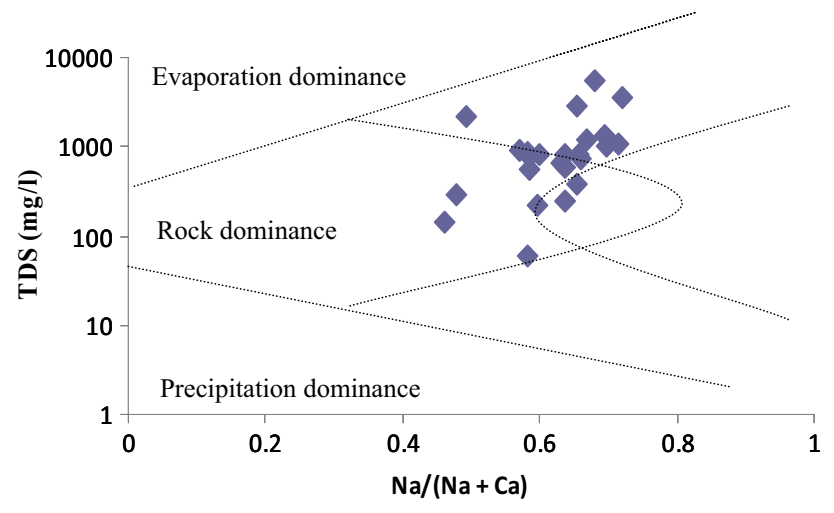

Fig. 3 Gibb's diagram for the factors regulating groundwater chemistry

fluoride reach urine. Spot samples of urine were collected in pre-cleaned polypropylene (PP) bottles of $50 \mathrm{ml}$ capacity. The collection of urine samples was done with prior intimation and consent of the parents; and approval from the institutional committee for ethics and research. Fluoride concentration in groundwater and urine samples was determined using a $\mathrm{F}^{-}$ion specific electrode (Orion 96-09 BNWP) fitted with an Orion Star A329 ISE Meter, MA, USA. A cross-sectional survey was also carried out (for 50 students) to assess the prevalence of dental fluorosis. Based on the prevalence, dental fluorosis was classified as nil, mild, moderate, and severe as per the Dean's Index (Dean 1942). Physicochemical characterization of groundwater was also performed using standard methods of APHA (Eaton et al. 1995) to get the information about possible soil-water chemistry governing the water quality. The statistical analysis of the results obtained was done on SPSS ver. 20. Analysis of correlation, cluster analysis, and principal component analysis were performed to understand the factors controlling groundwater chemistry.

\section{Results and discussion}

Based on the analysis of groundwater, it was observed that fluoride was within the permissible limit for most of the samples. It varied from $0.10-2.40 \mathrm{mg} / \mathrm{l}$ with an average value of $0.46 \mathrm{mg} / \mathrm{l}$ in groundwater (Table 1). Only one sample exceeded the standard prescribed limit of $1.0 \mathrm{mg} / \mathrm{l}$ (BIS 2012). Based on the recorded mean concentration, it may be inferred that exposure to fluoride from drinking water is not of much concern in the study area. However, spatial variations and observed value of $2.40 \mathrm{mg} / \mathrm{l}$ at one location indicates that the health of exposed population may be compromised at few places, particularly if the source is used for drinking water. Moreover, intake of more volume of water during early growing stage may result in fluorosis among children since most of the ingested minerals are absorbed by the body during growing stage (Whitford 1999). Absorption of fluoride is regulated by the diet as well. The population having more of vegetables in food is expected to excrete more of fluoride in urine compared to those who consume more of meat (WHO 2014). In the present study, urinary fluoride concentration varied from below the detection limit (BDL) to $1.8 \mathrm{mg} / \mathrm{l}$ for girls and $0.17-1.20 \mathrm{mg} / \mathrm{l}$ for boys, with a mean value of 0.34 and $0.65 \mathrm{mg} / \mathrm{l}$, respectively. Low concentration of urinary fluoride in girls may be attributed to relatively less consumption of drinking water and food compared to boys. The average level of fluoride in urine of boys was higher than in drinking water which may be an outcome of additional ingestion of fluoride via intake of tea, milk, vegetables, etc. Similar observations of higher $\mathrm{F}^{-}$in urine have been made in other studies too (Paez and Dapas 1983; Szymaczek and Lewicka 2005; Rango et al. 2014; Del Carmen et al. 2016) ascribing the reason to additional intake of bioavailable fluoride through food. Based on the survey for dental fluorosis, it was observed that majority of the subjects suffered from dental fluorosis with the degree of expression varying from nil to severe through mild and moderate as per Dean's Index. Prevalence of fluorosis was observed to be $77 \%$ among the girls, and $68 \%$ among the boys (Table 1). But based on the grading of intensity, most of the girls had mild fluorosis (48\%) followed by moderate (21\%) and severe (8\%). On the other hand, most of the boys suffered from moderate fluorosis (36\%) and relatively less from mild (24\%) and severe (8\%) (Fig. 1). More prevalence of moderate and severe dental fluorosis (44\%) among boys (As against $29 \%$ of girls) further strengthens the premise that boys had more ingestion of fluoride through food and water, and hence higher urinary fluoride concentration. Statistical evaluation for correlation between urinary fluoride concentration and prevalence of fluorosis, too, revealed relatively stronger correlation for boys (0.64) than the girls (0.44) ( $p$ value $>0.01)$. Calculations of correlation coefficients among different physico-chemical parameters revealed that fluoride is significantly and positively correlated with $\mathrm{Na}$ and $\mathrm{Ca}$ indicating the possible presence of fluorspar, fluoraptite, cryolite in sub surface soil/rocks. While determining the 
Table 3 Concentration of fluoride in groundwater and urine, and prevalence of dental fluorosis in different regions of the world

\begin{tabular}{|c|c|c|c|c|c|c|c|c|}
\hline S. No. & Country & Region & $\begin{array}{l}\text { Age group } \\
\text { (years) }\end{array}$ & $\begin{array}{l}\mathrm{F}^{-} \text {in drinking } \\
\text { water }(\mathrm{mg} / \mathrm{l})\end{array}$ & $\begin{array}{l}\mathrm{F}^{-} \text {in urine } \\
(\mathrm{mg} / \mathrm{l})\end{array}$ & $\begin{array}{l}\text { Prevalence of } \\
\text { dental fluoro- } \\
\text { sis }(\%)\end{array}$ & $\begin{array}{l}\text { Criteria for } \\
\text { classifica- } \\
\text { tion of dental } \\
\text { fluorosis }\end{array}$ & $\begin{array}{l}\text { Reference } \\
\text { (Remarks) }\end{array}$ \\
\hline 1. & India & $\begin{array}{c}\text { Bass Village, } \\
\text { Haryana }\end{array}$ & $15-18$ & $0.1-2.4$ & $0.17-1.80$ & 72.0 & DI & Present Study \\
\hline 2. & Mexico & $\begin{array}{l}\text { (a) Morelos } \\
\text { (b) Guanajuato }\end{array}$ & $\begin{array}{l}8-12 \\
11-20\end{array}$ & $\begin{array}{l}0.7-1.5 \\
4.4\end{array}$ & $\begin{array}{l}\text { NA } \\
0.50-6.65\end{array}$ & $\begin{array}{l}39.4-60.5 \\
91.90\end{array}$ & $\begin{array}{l}\text { TFI } \\
\text { TFI }\end{array}$ & $\begin{array}{l}\text { García-Pérez } \\
\text { et al. } 2013 \\
\text { Del Carmen } \\
\text { et al. } 2016\end{array}$ \\
\hline 3. & Ethiopia & $\begin{array}{l}\text { Ethiopian Rift } \\
\text { Valley }\end{array}$ & $10-15$ & $1.1-18.0$ & $1.1-39.8$ & 91.00 & TFI & $\begin{array}{l}\text { Rango et al. } \\
2014\end{array}$ \\
\hline 4. & China & $\begin{array}{l}\text { (a) Xinhuai } \\
\text { (b) Wamiao }\end{array}$ & $8-13$ & $\begin{array}{l}0.18-0.76 \\
0.57-4.50\end{array}$ & $\begin{array}{l}0.37-2.50 \\
0.90-12.50\end{array}$ & NA & - & $\begin{array}{l}\text { Xiang et al. } \\
2003 \\
\text { (Lower IQ level } \\
\text { related to } \\
\text { higher fluoride } \\
\text { in drinking } \\
\text { water) }\end{array}$ \\
\hline 5. & Poland & Poznan & $22-34$ & $0.40-0.80$ & $0.84-2.22$ & NA & - & $\begin{array}{r}\text { Szymaczek and } \\
\text { Lewicka } 2005\end{array}$ \\
\hline 6. & Venezuela & $\begin{array}{r}\text { Maracay, } \\
\text { Aragua }\end{array}$ & $1.25-6$ & $\begin{array}{l}0.07-0.09 \\
\text { (*average } \\
\text { total intake- } \\
\mathrm{mg} / \mathrm{kg} / \text { day })\end{array}$ & $\begin{array}{c}0.79-0.92 \\
\text { (average } \\
\text { values) }\end{array}$ & NA & - & $\begin{array}{l}\text { Hector et al. } \\
2009\end{array}$ \\
\hline 7. & Rajasthan & $\begin{array}{l}\text { (a) Banswara } \\
\text { (b) Dungarpur } \\
\text { (c) Udaipur }\end{array}$ & $17-22$ & $1.5-4.0$ & NA & 77.11 & DI & Choubisa 2001 \\
\hline 8. & $\begin{array}{l}\text { India } \\
\text { (Haryana } \\
\text { State) }\end{array}$ & $\begin{array}{l}\text { (a) Jhajjar City } \\
\text { (b) Dadanpur } \\
\text { Village } \\
\text { (c) Dariyapur } \\
\text { Village }\end{array}$ & $8-15$ & $\begin{array}{l}1.90-2.60 \\
2.53-3.14 \\
1.63-3.33\end{array}$ & $\begin{array}{l}0.05-2.64 \\
0.69-2.80 \\
0.31-2.50\end{array}$ & $\begin{array}{l}51.90 \\
94.63 \\
36.84\end{array}$ & TSIF & $\begin{array}{l}\text { Kumar et al. } \\
2017\end{array}$ \\
\hline 9. & $\begin{array}{l}\text { India (Haryana } \\
\text { State) }\end{array}$ & $\begin{array}{l}\text { (a) Beri Block } \\
\text { (b) Bahadur- } \\
\text { garh } \\
\text { (c) Jhajjar } \\
\text { Block } \\
\text { (d) Sahlawas } \\
\text { Block } \\
\text { (e) Matanhail } \\
\text { Block }\end{array}$ & $7-15$ & $\begin{array}{l}1.56-3.05 \\
1.53-3.52 \\
1.52-4.00 \\
1.53-3.14 \\
1.52-3.16\end{array}$ & NA & $\begin{array}{l}59.76 \\
66.32 \\
44.99 \\
58.02 \\
62.10\end{array}$ & TSIF & $\begin{array}{l}\text { Yadav et al. } \\
2009\end{array}$ \\
\hline
\end{tabular}

DI Dean's Index, TFI Thylstrup and Fejerskov Index, TSIF Tooth Surface Index of Fluorosis (Horowitz et al. 1984), NA not analysed

suitability of groundwater, the only source for drinking, it was observed that the quality was compromised with respect to total dissolved solids (TDS), total hardness (TH), $\mathrm{Mg}, \mathrm{Fe}$ and $\mathrm{SO}_{4}{ }^{2-}$ chiefly (Table 2), apart from the effect of fluoride. A comparative analysis of concentration of fluoride in drinking water, urine, and prevalence of fluorosis in schoolchildren around the world has been made in Table 3 .

Hydro-geochemical classification of the ground water revealed that most of the samples were $\mathrm{CaHCO}_{3}$ type or mixed $\mathrm{CaNaHCO}_{3}$ type. Piper tri-linear classification (Piper 1953) indicated that the alkaline $\left(\mathrm{Na}^{+}\right.$and $\left.\mathrm{K}^{+}\right)$species exceeded the alkaline earth $\left(\mathrm{Ca}^{2+}\right.$ and $\left.\mathrm{Mg}^{2+}\right)$; and weak acids $\left(\mathrm{CO}_{3}{ }^{2-}\right.$ and $\left.\mathrm{HCO}_{3}{ }^{-}\right)$exceeded strong acids $\left(\mathrm{Cl}^{-}\right.$and $\left.\mathrm{SO}_{4}{ }^{2-}\right)$ (Fig. 2). Based on the values of baseexchange (Matthess 1982) all the samples were found to be sodium sulfate typed (value $<1$ ) except one sample. Negative values of chlor-alkaline index (Schoeller 1977) suggest that most of the sample had direct base-exchange reaction resulting in exchange of $\mathrm{Ca}$ and $\mathrm{Mg}$ of rocks/ soil with $\mathrm{Na}$ and $\mathrm{K}$ of water. Gibbs classification (Gibbs 1970) to determine the major regulating factor revealed that the quality of ground water is predominately governed by rock-water interaction (Fig. 3). The average values of ratio of $\mathrm{Ca} / \mathrm{Na}(0.72), \mathrm{Mg} / \mathrm{Na}(1.15)$, and $\mathrm{HCO}_{3} / \mathrm{Na}(3.84)$ 
Table 4 Principal component analysis of observed parameters in the present study

\begin{tabular}{|c|c|c|c|c|}
\hline \multirow[t]{2}{*}{ Variables } & \multicolumn{4}{|c|}{ Component } \\
\hline & 1 & 2 & 3 & 4 \\
\hline $\mathrm{pH}$ & -0.50 & 0.32 & 0.66 & 0.14 \\
\hline $\mathrm{EC}$ & 0.33 & 0.85 & -0.21 & -0.05 \\
\hline TDS & 0.33 & 0.85 & -0.20 & -0.05 \\
\hline $\mathrm{TH}$ & 0.85 & -0.45 & 0.03 & -0.18 \\
\hline $\mathrm{TA}$ & 0.95 & -0.13 & 0.21 & 0.01 \\
\hline $\mathrm{Na}$ & 0.86 & 0.35 & 0.27 & 0.12 \\
\hline K & 0.37 & -0.45 & -0.42 & -0.07 \\
\hline $\mathrm{Ca}$ & 0.90 & 0.28 & 0.01 & -0.04 \\
\hline $\mathrm{Mg}$ & 0.77 & -0.56 & 0.13 & -0.07 \\
\hline $\mathrm{Li}$ & 0.95 & -0.06 & 0.06 & 0.04 \\
\hline $\mathrm{Fe}$ & 0.15 & 0.09 & -0.07 & 0.89 \\
\hline $\mathrm{CO}_{3}^{2-}$ & 0.73 & -0.38 & 0.51 & 0.08 \\
\hline $\mathrm{HCO}_{3}^{-}$ & 0.93 & 0.07 & -0.06 & -0.05 \\
\hline $\mathrm{Cl}^{-}$ & 0.80 & 0.12 & -0.18 & -0.31 \\
\hline $\mathrm{SO}_{4}^{2-}$ & 0.83 & 0.16 & -0.23 & 0.08 \\
\hline $\mathrm{NO}_{3}^{-}$ & 0.51 & -0.31 & -0.21 & 0.45 \\
\hline $\mathrm{PO}_{4}{ }^{3-}$ & 0.72 & 0.04 & 0.33 & 0.02 \\
\hline $\mathrm{F}^{-}$ & 0.35 & 0.70 & 0.41 & -0.06 \\
\hline Eigen values & 9.054 & 3.301 & 2.122 & 1.195 \\
\hline $\mathrm{CV}(\%)$ & 47.66 & 65.03 & 76.20 & 82.49 \\
\hline
\end{tabular}

Statistically significant $p$ values are in bold $(p<0.05)$

indicated that silicate weathering primarily governs water chemistry (Negrel et al. 1993) followed by carbonate weathering as represented by high average value (5.82) of $(\mathrm{Ca}+\mathrm{Mg}) /(\mathrm{Na}+\mathrm{K})$ ratio.

\section{Statistical analysis}

The statistical analysis of the results obtained revealed that a significant positive correlation of fluoride existed with sodium, TDS, and EC indicating to natural dissolution of fluoride from the underlying strata. Among the other ions, significant positive correlation of $\mathrm{Na}$ was observed with $\mathrm{Ca}$, $\mathrm{Li}, \mathrm{CO}_{3}{ }^{2-}, \mathrm{HCO}_{3}{ }^{-}, \mathrm{Cl}^{-}, \mathrm{SO}_{4}{ }^{2-}$ etc. and these ions significantly contributed to total alkalinity and total hardness of water. Principal component analysis (PCA) (Table 4) also revealed that total alkalinity, total hardness, sodium, potassium, lithium, calcium, magnesium, carbonate, bicarbonate, chloride, and sulphate regulated the water quality; and indicates that the source is primarily natural. A hierarchical cluster analysis using Centroid Linkage was performed to highlight the inter-relationships among various sites along with the selected water parameters. The dendrogram classified the data into three cluster membership. First cluster includes all the sites except site 21 (second cluster), and site 23 (third cluster) (Fig. 4). Cluster analysis indicated that the water quality is almost the same with the only variation at two sites (Site 21 and 23).

\section{Conclusion}

The study concludes that the concentration of fluoride in groundwater in Bass village is within the prescribed limits except a few locations. Although intake through drinking water is limited, ingestion of fluoride through food, tea, milk, toothpaste, etc., may be alternate route for exposure. Depending upon the total daily ingestion, boys are more exposed to fluoride as observed in higher average urinary fluoride level. It has lead to more severe cases of dental fluorosis among the boys than the girls. Significant number of cases of dental fluorosis (72\%) despite a relatively lower concentration of fluoride in drinking, as compared to other studies around the world, is a cause of concern. The study recommends extensive screening of groundwater sources for fluoride levels, and a regular monitoring of 24-h urine samples for a bigger sample size to better understand 


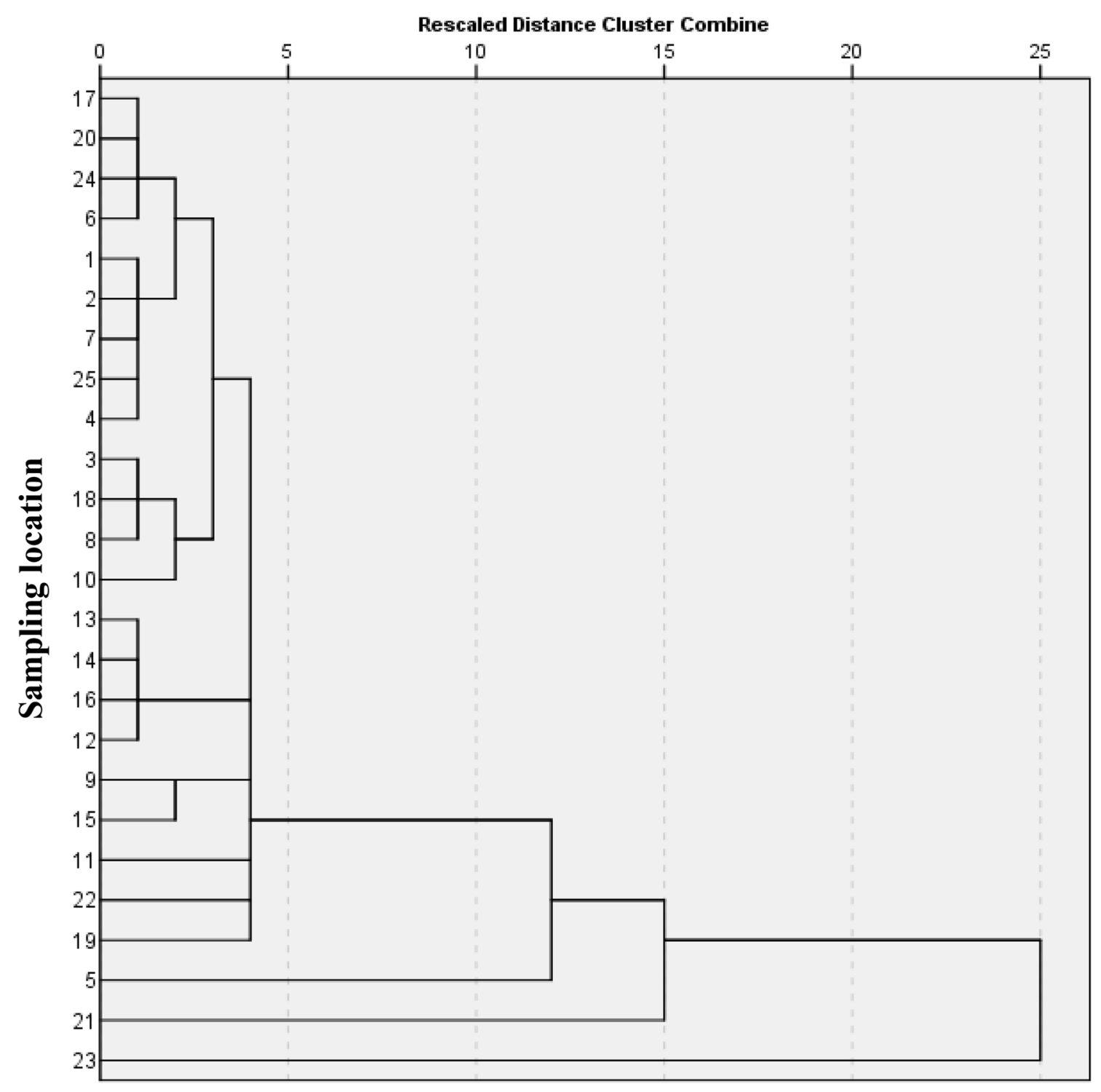

Fig. 4 Cluster analysis of the locations with respect to analysed parameters

the exposure to fluoride, and its control. Further, suitable treatment of groundwater may be targeted to improve water quality especially for dissolved solids, hardness, magnesium ions, and dissolved iron for use in drinking.

Acknowledgements The authors acknowledge the help of Mr. Vinod Vats, Vice Principal, GSSS, Bass Village during sample collection.

Open Access This article is distributed under the terms of the Creative Commons Attribution 4.0 International License (http://creativeco mmons.org/licenses/by/4.0/), which permits unrestricted use, distribution, and reproduction in any medium, provided you give appropriate credit to the original author(s) and the source, provide a link to the Creative Commons license, and indicate if changes were made.

\section{References}

Bureau of Indian Standards (BIS) (2012) Indian standard drinking water specifications (Second Revision) BIS 10500. BIS, New Delhi

Choubisa SL (2001) Endemic fluorosis in Southern Rajasthan, India. Fluoride 34(1):61-70

Dean HT (1942) The Investigation of physiological effects by the epidemiological method. In: Moulton FR (ed). Fluorine and dental health. Washington, DC: American Association for the Advancement of Science, Publication No. 19: 23-31

Del Carmen AF, Javier FH, Aline CC (2016) Dental fluorosis, fluoride in urine, and nutritional status in adolescent students living in rural areas of Guanajuato, Mexico. J Int Soc Prev Community Dent 6(6):517-522

Eaton AD, Clesceri LS, Greenberg AE (1995) Standard methods for the examination of water and wastewater, 19th edn. APHA, New York 
García-Pérez A, Irigoyen-Camacho ME, Borges-Yáñez A (2013) Fluorosis and dental caries in mexican schoolchildren residing in areas with different water fluoride concentrations and receiving fluoridated salt. Caries Res 47:299-308

Gibbs RJ (1970) Mechanism controlling world water chemistry. Science 17:1088-1090

Haritash AK, Kaushik CP, Kaushik A, Kansal A, Yadav AK (2008) Suitability assessment of groundwater in some villages of Rewari district in Haryana. Environ Monit Assess 145(1-3):397-406

Haritash AK, Gaur S, Garg S (2016) Assessment of water quality and suitability analysis of River Ganga in Rishikesh, India. Appl Water Sci 6:383-392

Haritash AK, Mathur K, Singh P, Singh SK (2017) Hydrochemical characterization and suitability assessment of groundwater in Baga-Calangute stretch of Goa, India. Environ Earth Sci 6:341. https://doi.org/10.1007/s12665-017-6679-5

Hector F, Maria A, Margaret P, Anthony V, Fatima R (2009) Fluoride intake and urinary fluoride excretion in children attending a daycare center in Maracay, Aragua state, Venezuela. J Dent Oral Hyg 1(3):027-035

Horowitz HS, Driscoll WS, Meyers RJ, Heifetz SB, Kingman A (1984) A new method for assessing the prevalence of dental fluorosisthe Tooth Surface Index of Fluorosis. J Am Dent Assoc 109:37-41

International Programme on Chemical Safety (IPCS) (2002) Fluoridesenvironmental health criteria: 227. WHO, Geneva

Jolly S, Singla V, Sharma R, Ralhan S, Sandhu S (1974) Endocrine aspects of endemic fluorosis. Fluoride 7:208-219

Kumar S, Lata S, Yadav J, Yadav JP (2017) Relationship between water, urine and serum fluoride and fluorosis in school-children of Jhajjar District, Haryana, India. Appl Water Sci 7:3377-3384

Matthess G (1982) The properties of groundwater, 1st edn. Wiley Publishers, New York

Negrel P, Allegre CJ, Dupre B, Lewin E (1993) Erosion sources determined by inversion of major and trace elements ratios and strontium isotopic ratios in river water: the Congo basin case. Earth Planet Sci Lett 120:59-76

Paez D, Dapas O (1983) Biochemistry of fluorosis X-comparative study of the Fluoride levels in biological fluids. Fluoride 15:88-96

Piper AM (1953) A graphic procedure in geochemical interpretation of water analysis. United States Geological Survey (USGS) Groundwater Note, No. 12
Rango T, Vengosh A, Jeuland M, Tekle-Haimanot R, Weinthal E, Kravchenko J, Paul C, McCornick P (2014) Fluoride exposure from groundwater as reflected by urinary fluoride and children's dental fluorosis in the Main Ethiopian Rift Valley. Sci Total Environ 496:188-197

Schoeller H (1977) Geochemistry of groundwater. In: Groundwater studies-an international guide for research and practice, vol 15. The UNESCO Press, Paris, pp 1-18

Szymaczek J, Lewicka M (2005) Urinary fluoride levels for assessment of fluoride exposure of pregnant women in Poznan, Poland. Fluoride 38(4):312-317

Whitford GM (1999) Fluoride metabolism and excretion in children. J Public Health Dent 59:224-228

World Health Organization (WHO) (2002) Environmental health criteria-fluoride. WHO, Geneva, p 227

World Health Organization (WHO) (2006) Guidelines for drinking water quality. First addendum to 3rd Ed.n, Vol. 1, Geneva

World Health Organization (WHO) (2014) Basic methods for assessment of renal fluoride excretion in community prevention programmes for oral health. WHO, Geneva

Xiang Q, Liang Y, Chen L, Wang C, Chen B, Chen X, Zhou M (2003) Effect of fluoride in drinking water on children's intelligence. Fluoride 36(2):84-94

Yadav AK, Kaushik CP, Haritash AK, Singh B, Raghuvanshi SP, Kansal A (2007) Determination of exposure and probable ingestion of fluoride through tea, toothpaste, tobacco, and pan masala. J Hazard Mater 142:77-80

Yadav JP, Lata S, Kataria SK, Kumar S (2009) Fluoride distribution in groundwater and survey of dental fluorosis among school-children in villages of Jhajjar District of Haryana, India. Environ Geochem Health 31:431-438

Zhao LB, Liang GH, Zhang DN, Wu XR (1996) Effect of fluoride a high-fluoride water supply on children's intelligence. Fluoride 29:190-192

Publisher's Note Springer Nature remains neutral with regard to jurisdictional claims in published maps and institutional affiliations. 